coveries under the ban of suspicion. In the January number, 1886, of the same magazine, there also appeared an elaborate attack by its editor upon the authenticity of the Davenport tablets, of which the Rev. J. Gass was a principal discoverer. In the March number there further appeared a communication from Mr. A. F. Berlin, containing the statements that Rev. Mr. Gass had made some exchanges, not with bimself, but with Mr. H. C. Stevens of Oregon, and that most of the mound-relics sent by Mr. Gass to Mr. Stevens were 'modern' or fraudulent. These statements were submitted by the writer to Mr. Gass, and his explanations as furnished to me will be found in the following communication. This letter from Mr. Gass was written in German; and the translation herewith furnished for publication was made by Prof. William Riepe, who was formerly connected with the public schools of this city, and subsequently revised by Carl L. Suksdorf, Esq., principal of the German free school. It is proper to state that Mr. Gass preaches and teaches in German, and as his few English letters, on account of his imperfect knowledge of the language, are usually dictated to an impromptu amanuensis, they but imperfectly represent his precise meaning.

The publications in the Antiquarian were made without communication with the Davenport academy, and without affording Mr. Gass an opportunity for explanation. In correspondence with Mr. Berlin, the writer represented that Mr. Gass should have an opportunity to inspect the relics in question, and requested that they should be forwarded to the Davenport academy for this purpose. This request was declined. The statement of $\mathrm{Mr}$. Gass should have appeared in the Antiquarian; but as we are denied admission to its columns, except under restrictions neither the Davenport academy nor Mr. Gass could accept, we shall have to ask of you the favor of its early publication.

In conclusion, permit me to say, that, while the members of the Davenport academy have the most unbounded confidence in the integrity and good faith of Rev. Mr. Gass, it should be stated that the question of the authenticity of its inscribed tablets does not by any means wholly depend upon his reliability. As may be seen from our published statements, there were other persons present at the discovery of these relics, and certificates as to the facts made by these well-known and highly esteemed citizens are preserved among the archives of the academy. These additional evidences have never yet been given to the public, and, when published, will furnish strong corroborative proof of the genuineness of the relics in question.

It is always to be deplored when personal considerations enter into scientific discussions, but in archeological research, where the question of the authenticity of relics so largely depends upon the integrity of the explorer, character becomes an important factor, and is a legitimate subject for inquiry. In cases like that under consideration, however, this moral test should be sternly applied alike to the accuser and the accused. Chardis E. Putnam,

President Davenport academy of sciences. Davenport, Io., May 6.

[Communication from Rev. J. Gass.]

Charles E. Putnam, Esq.

Dear Sir, - In accordance with your request, I will hasten to give you an account, so far as it is still now possible for me to do, of my transactions with Mr. H. C. Stevens of Oregon City, Ore., in regard to the relics in question.

I formerly often received letters and circulars offering me relics, or wishing to exchange or buy from me. Among others I received also in April, 1881 , a postal-card from Mr. Stevens. This I handed to our curator of the academy, Mr. W. H. Pratt, as I had not the least intention to make any exchange with him myself. To our curator, however, the offer was quite welcome, and he authorized me to write to Mr. Stevens that he was willing to make such exchanges. Mr. Stevens immediately sent a number of relics which pleased us all very well. At this time, I do not know positively whether before or after I had seen those articles, awoke in me the very unhappy wish, as it now appears, to possess a few good small arrow-heads to be used as charms for my little daughter. I therefore collected what was in the house, the best of which was a small box of flint implements which I had received from Rev. C. Mutschmann of Missouri. All these were of a primitive character, and therefore not of especial value for our museum. Among the objects received from Pastor Mutschmann there were a small stone axe, an Indian stone pipe, and also fragments of such a one. The pipe had about the following form :

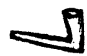

It was of grayish color, rough, without polish. The broken one was of a similar character. Pastor Mutschmann wrote to me at that time that he was told that the pipe was found in an Indian grave on the Missouri River, I believe in St. Charles or Warren county. I took the pipes and other relics without any doubt as to their genuineness, and did not test them in any way. I supposed the material to be gray pipe-stone.

I packed all, as I had received them, in two paper boxes, and sent them by mail to Mr. Stevens. Thereupon I received from him a number of small arrowheads, of which a few were nice and whole, but the most were broken. At the same time I received a letter from Mr. Stevens, in which he remarked that the articles sent were not worth the postage I had paid, for it was all broken, worthless stuff. In my answer I endeavored to defend the relics as not being entirely worthless ; and, somewhat hurt and irritated by what I considered the unjust remarks of Mr. Stevens, I have, as I now see, somewhat overestimated the value of those articles. He remarked at the same time that the pipes were not old (ancient). Indian pipes, but were modern, made by white people; at least, some one had told him so. I gave no credit to this statement, but took it for an empty excuse made in order to give me little or nothing for them. If I had entertained the least doubt of their genuineness, I would not, under any circumstances, have sent them; or at least, after Mr. Stevens had made these remarks, I should certainly at once have asked them, and taken them back at any price.

As to who has written my letters for me, I cannot now say positively. Mrs. Gass says it was certainly done by one of my pupils, and I believe she is right. A letter in German, written by myself, would surely have sounded quite differently. These unfortunate letters have, however, been sent in my name, and with my name, and I must now abide the consequences, come what will. I can scarcely under- 
stand, even now (supposing that Mr. Berlin's copy of my letter is correct), how the incorrect statement that the academy had bought such pipes, and paid such high prices for them, could have occurred unobserved. The boy who wrote the letter for me must have misunderstood me, and from my ignorance of the English language I overlooked this error. It may be, that, not attaching much importance to this letter, I may have sent it without first examining or looking it over.

In regard to the relics in question, it is impossible at present for me to determine whether those which $\mathrm{Mr}$. Stevens claims to have received from me are actually the objects which I have sent him; for I have not seen them as yet, and for the present shall have no opportunity, as Mr. Berlin has informed you that he could not send them for my inspection without the consent of Mr. Stevens. On the contrary, Mr. Stevens says that they no longer belong to him, but to Mr. Berlin.

Immediately on receiving your first communication on this matter, I resolved to send back to him the arrow-heads received in exchange, and to request him also to return those which he claimed were not genuine to me. Mr. Stevens returned the package to me, and refused to give me back those which he claimed I had sent to him, with the excuse that they were no longer in his possession, as he had given them to Mr. Berlin. Hence obviously it is impossible for me to determine as to the correctness of the statements made by those gentlemen concerning said relics. Their refusal to allow me to inspect the objects is very strange and perplexing to me.

As Mr. Stevens informs us that many of the relics I sent him were thrown out in the yard on a pile of other rejected relics, and have been lying there some years exposed to the weather, it is no wonder they became, as he says, considerably changed in appearance, and the labels lost. Under these circumstances, and after so long a time, it must have been very difficult for him to select the relics in question, and to distinguish them with certainty from those received from other sources in his extensive exchanges. I have no doubt, if I could see the relics, I should recognize many or most of them, unless they have been so changed by Mr. Stevens as to be no longer recognizable. Until this opportunity is afforded, the present account of the transaction must suffice.

That the intention or the thought of having any thing to do with doubtful relics, or of deceiving any one with them, was far from my mind, will, to you, scarcely require any special assurance from me.

Postville, Io., April 10.

J. GAss.

The above is a correct translation from the German of a communication written by Rev. J. Gass to Charles E. Putnam, Esq., hearing date April 10, 1886. Carl L. Suksdorf.

Davenport, Io., May 4. WM. KIEPE.

\section{What was the rose of Sharon?}

An interesting question is renewed, in a late number of the Edinburgh review, on ' What was the rose of Sharon?' It is very possible that some of the readers of Science may be able to throw further light upon the subject, or at least give trustworthy opinions as to the merits of 'crocus,' ' narcissus,' or
' reed.' The extract is, I hope, of sufficient interest to merit republication : it is as follows :-

"The 'rose of Sharon' has long been a disputed point. The Hebrew word khabatseleth occurs only in Canticles ii. 1, and Isa. xxxv. 1. The Revised version reads 'rose' in the text, and 'autumn crocus' in the margin. We are of opinion that the narcissus (N. tazetta) is intended. The scene of the Canticles is in the spring, when the narcissus would be in blossom: it is very sweet, has long been and still is a plant of which the orientals are passionately fond. Hasselquist noticed it on the plain of Sharon; Tristram, in cultivated land and lower hills from Gaza to Lebanon; Mr. H. Chichester Hart, in the districts between Yebdna and Jaffu (plain of Sharon). 'Some low-lying patches,' he says, 'were quite white with it.' The October quarterly statement (Palestine exploration fund) contains a valuable paper by Mr. C. Hart, entitled 'A naturalist's journey to Sinai, Petra, and South Palestine, made in the autumn of 1883.' The autumn crocus has no perfume, and would not be in bloom till late in the year. The narcissus is a bulbous plant, which is apparently implied in part of its Hebrew name; i.e., betsel (a 'bulb,' an 'onion'). But quite a different plant has very recently appeared as the claimant to the honor of being the 'rose of Sharon:' an Assyrian plant name is introduced to us by Dr. F. Delitzsch. Among the names of different kinds of kînû ('reed') and of objects made of it, occurring on a tablet in the British museum, and published in 'The cuneiform inscriptions of western Asia,' mention is made of one called khabatsillatu, which in sound is identical with the Hebrew name in Canticles and Isaiah; so that Dr. F. Delitzsch, without a moment's hesitation, upsets all other floral aspirants with one decided blow, and reads ' reed of Sharon,' 'the desert shall rejoice and sprout like the reed.'"

\section{Thermometer exposure and the contour of the earth's surface.}

Various writers during the last hundred years, and perhaps earlier, have called attention to the marked differences of temperature which are frequently to be found in clear weather between hill-tops and adjacent valieys. Recently Hann and Woeikof in Europe have written numerous papers on the subject; and in this country instances have been given by J. W. Chickering, jun., and S. Alexander (American meteorological journal), Professor Mendenhall (Science), Professor Hazen (Professional paper of the signal service, xviii.), and Prof. W. M. Davis ( $A p$ palachia). But attention has not generally been attracted to the bearing these differences of temperature have on the subject of thermometer exposure.

My attention was drawn to the subject by the marked differences of temperature which were reported by different observers at Ann Arbor, Mich., during the cold period of the winter of 1885 ; and, in order to study the subject, a regular series of observations were begun between the astronomical observatory at Ann Arbor and an adjacent valley through which ran the Huron River. The bottom of the valley was about a hundred and fifty feet lower than the land on each side of it, and was about a quarter of a mile distant from the side on which stood the observatory. The method employed was to obtain the temperature at the observatory by means of a sling thermometer; then descending the 